Demchyshyn, M.G., and Kril, T.V.

Institute of Geological Sciences, the NAS of Ukraine,

55 b, 0. Gonchar St., Kyiv, 01054, Ukraine,

+380 44486 3023, DemchyshynMG@nas.gov.ua

\title{
IMPROVEMENT OF THE ENGINEERING PROTECTION SYSTEMS OF THE KYIV-PECHERSK LAVRA RESERVE TERRITORY
}

Introduction. The territory of the Kyiv-Pechersk Lavra reserve is located in difficult engineering and geological conditions on the right-bank slopes of the Dnieper River valley and adjacent areas of the loess plateau. The stability and preservation of Lavra's objects is ensured by special systems of engineering protection (retaining and water-regulating structures).

Problem Statement. Most of these structures were built in different periods and did not always have proper justification and configuration. With the development of the Reserve, the conditions have changed for their operation, thus, there is a need to review their effectiveness as protective structures and to improve them.

Purpose. Determination of feasibility, adequacy, efficiency, and condition of engineering protection systems of the Reserve to improve them and to prevent emergencies.

Materials and Methods. The scheme of engineering protection of the territory (scale 1:1000); the plan of the current state of the Reserve (scale 1:1000); data of engineering and geological surveys, historical and archaeological materials are used. To determine the condition of engineering protection objects, field observations have been carried out (installation of marks, photo fixation). To assess the stability of the Reserve, mechanical and mathematical principles of engineering geology have been used in conjunction with the approaches of system analysis and the theory of engineering and geological similarity.

Results. The landslides in this area have been established to be caused by active erosion of the right bank of the Dnieper River, significant amount of earthworks during the construction of the Pechersk fortress in the $17^{\text {th }}-18^{\text {th }}$ centuries, as well as by engineering structures that are inadequate to the scale and nature of geological processes and by their low efficiency.

Conclusions. Improvement of engineering protection systems implies raising the level of their maintenance, combining the maintenance works with the landscaping and gardening activities, establishing a monitoring system, and taking into consideration the seasonality and abnormality of hydrometeorological processes. The implementation of the obtained R\&D results will raise the effectiveness of engineering protection systems for the protection and preservation of objects of the Reserve.

Keywords: engineering and geological conditions, landslide, gaps, suffusion, engineering protection, strengthening of the slopes.

The formation of National Kyiv-Pechersk Historical and Cultural Reserve (hereinafter referred to as the Reserve) as historical and architectural ensemble, the World Heritage Site (No. 527 on

(C) DEMCHYSHYN, M.G., and KRIL, T.V., 2019 the UNESCO list) took place since $10^{\text {th }}$ century on the steep slopes of the Dnieper valley and the adjacent areas of the forest plateau. The Reserve being located between the Spassky (Pankratievsky), Lavra, and Zalavrsky Ravines, the engineering geological conditions of the area are compli- 
cated by periodic activation of geological processes. In order to ensure the stability and reliable exploitation of religious buildings in the Lavra area, the slopes as well as the right bank hills of Kyiv, in general, were reinforced throughout centuries. In particular, in his PhD work, I.M. Kyrychko [1] has noted that despite engineers tried to control landslides since ancient times, antilandslide structures were constructed from time to time. Periodic destruction of buildings and rock slides on the slopes were remedied without taking into account the causes of landslides and engineering geological parameters of the hills.

In archived historical and geological studies, as well as in newspapers and journal until the early $19^{\text {th }}$ century, there were extremely rare descriptions and historical data on the progress of landslides and efforts to control them in Kyiv, while information available in other literary sources is not sufficient.

In the last centuries, the Dnieper slopes have been reinforced by doing periodical landscaping works, constructing retaining walls, drainage, and various artificial structures. Over the past decades, Kyioproject, InzhProject, and State Research Institute of Civil Engineering Structures, have been designing the anti-landslide works for engineering protection of Lavra, while Specialized Administration for Anti-Landslide Underground Works has been providing supervision and repair works.

At the same time, there have been reported numerous cases when landslides, sinks, and other exogenous geological processes (EGP) are caused by construction of engineering structures for protecting the territory or by unsatisfactory operation of the territory. Thus, within the period of observations, from 1939 to nowadays, the share of tunnel drainage systems (TDS) in the development of EGP on the slopes reaches $19 \%$ and is the highest among all manmade factors that affect these processes. However, despite continuously increasing number of protective structures, the development of various EGP has not stopped. Moreover, a considerable number of land- slides has been caused by the construction and operation of the TDS [2-4].

Assessing the reasonableness, adequacy, efficiency, and status of the Reserve's engineering protection systems will improve the engineering systems for protecting the Reserve's territory, preserving the world-class cultural heritage, and preventing emergencies.

In this research, the historical materials and materials of archeological researches concerning the central historical part of Kyiv, as well as the status of this territory in the past have been studied; the territory and structures located there (in particular, the retaining and drainage facilities) have been surveyed in order to compare their current condition with previous situation. The territory has been analyzed based on topographic materials at a scale of 1: 1000 and 1: 500 for some sites, using engineering and geological survey data, based on which changes in the outlines of ravine systems have been identified. Using the published materials [5-8] and the materials of the general schemes of anti-landslide measures, the time and nature of gravitational soil displacements on the edges and depression lines of the Spassky (Pankratievsky) and the Lavra ravine systems have been established.

Also, the hydrogeological conditions of the Reserve's territory have been studied based on the data of multi-year observations of water table in hydrogeological wells, taking into account the materials of geophysical researches carried out within the framework of project [2]. The specific features of relief, hydrography, and vegetation, which are required for arranging the surface water discharge, improving the territory, reinforcing the building foundations, and ensuring an engineering protection of the territory have been analyzed.

\section{GEOLOGICAL PRECONDITIONS FOR THE FORMATION OF THE RESERVE'S TERRITORY}

The engineering and geological conditions of the Reserve on the slope sections from Askold's Grave Park to the Navodnytsky Ravine are re- 
garded as complicated. To the foot of the riverside hill there adjoins a narrow $(50-100 \mathrm{~m})$ tract of the Dnieper floodplain terrace. It is covered with displaced formations, ravine alluvium, and present-day anthropogenic formations on which Naberezhne Highway is constructed. The slope height above the normal banked-up water level of the Kaniv Reservoir $(91.5 \mathrm{~m})$ is more than $100 \mathrm{~m}$, its average steepness is $23-26^{\circ}$. In this section of the slope, there are large ravine systems: Zalavrska, Lavra, and Spasska (Pankratievska) ones, which partition the hill from the upper edge to the water cut in the Dnieper [3, 9].

Structurally, this site belongs to the Pechersk anticlinal elevation and, from surface downward, consists of loess (up to $15 \mathrm{~m}$ ) under which there are sandy and clay rocks of the Dnieper glacial anthropogene complex. The hydrogeological conditions of the Reserve's territory are determined by the aquifers in the Quaternary eolian-deluvial and lacustrine-glacial deposits on the plateau (the Upper Lavra), in the Quaternary deluvial soils on the hills, and in the Oligocene (Kharkov) sands. The deep (up to $80 \mathrm{~m}$ ) Lavra ravine divides the Reserve into two almost equal parts, the Upper and the Lower Lavras [3]. The monuments of architecture of the Upper Lavra are located within the boundaries of the Kyiv loess plateau with elevations of 170-198 m. The Lower Lavra located on the slopes of the Dnieper and the Lavra ravine stands on brown and mottled clays and sands of the Newpetrovska and Mezhigirska rock formations.

Before the foundation of Kyiv and the start of intensive development of the Dnieper hills, here, according to the chronicles, "... there were a large forest and a pinewood..." [10], as a result of the natural development that took place in the Holocene and ensured the natural stability of the territory and the control of EGP, in particular, erosion and gravity-driven processes.

The first impacts on the natural state of the rock massif of this territory were associated with the construction and development of caves (in the $10^{\text {th }}$ century). The cave location was determined by the geological structure of the hills, i.e. outcropping of sandstones of the Poltava rock formation. As a result of the natural development, the formed niches were used as a place of refuge for pilgrims and other people. The Far (Varangian) and the Near Caves formed in the Poltava rock formations ("weak" sandstones) on the right and left sides of the Lavra ravine, respectively, with absolute elevations of 140-145 $\mathrm{m}$ and a total length of more than $500 \mathrm{~m}$, are especially important in historical terms.

With the adoption of Christianity, the caves became a place of residence of the monks, as well as a place of their burial. Since that time, they have undergone many landslides, especially, in the Near Caves after the earthquake in 1620. Today, as a result of accidental leakages from water pipes and improper surface water discharge systems, the soil massif on which the caves are located has been waterlogged. This leads to numerous collapses of vaults, destruction of brickwork and sinks of soil from the walls. So, in the spring of 2002 and in December 2003, long-term discharges from the water supply pipes led to collapsing a vault in the Near Caves. The sink was about $3 \mathrm{~m}^{3}$ $[2,3]$. Today, the caves are a place of destination of pilgrimage and listed in the historical and architectural monuments of Ukraine and the world.

Subsequently, there were constructed the Assumption Cathedral (1073), the St. Anna Conception Church at the entrance to the Far Caves (1679), and so on.

Since the beginning of the 10th century, as the first settlements on this territory appeared, Kyiv Dukes were expanding their residences in the village of Berestovo. Naturally, in everyday life and for construction purposes, people used wood and took it as close as possible, from the hills of the Dnieper valley. By the $12^{\text {th }}-13^{\text {th }}$ centuries, the forest devastation and intensive earthworks on the slopes had activated EGPs, in particular, ravine erosions and landslides, with all these processes taking place in close paragenesis.

In addition to meteorological conditions and geological structure, the formation of this terri- 
tory, from the Spassky to the Navodnytsky Ravine and Vydubychi, and, in particular, the development of the EGPs, are affected by tectonics, hydrology, and changes in the hydrological conditions, especially via an active influence of the stream from the left Dnieper arm (Desenka (Chortoryi)), which ran exactly on the right side of the Lavra Ravine and changed its course after the closure at the mouth of the Desna River.

The Dnieper River valley in this part was formed with a clearly defined right asymmetry as a result of the merger of the mainstream and its left tributary, the Desna River (Fig. 1). The power stream from the Desenka River filled with the Dnieper waters came to this territory and activated here the changes in the bank lines.

In 1850, because of the need to change the hydrological conditions of the Dnieper River near Kyiv, across the Desenka (Chortoryi) River there was built a dam near the mouth of the Desna River, to direct the mainstream along the western arm in order to improve the navigation conditions. On the one hand, it had a favorable result, while, on the other hand, it resulted in washing out the alluvial cones that were counterforces for the ravine alluvium laying higher, on the hill.

\section{LAVRA ENGINEERING PROTECTION STRUCTURES}

The engineering protection buildings for retaining the soil masses, draining and removing the surface and ground waters were constructed in the $16^{\text {th }}-18^{\text {th }}$ centuries [3]. Fig. 2 shows a wide system of earthworks, stone and brick fences, retaining walls, underground drainage galleries and tunnels built at different times and for different purposes in the Reserve's territory. These engineering structures had a defensive purpose or were used to develop the territory during the construction or shaping of relief. Subsequently, some of them lost their original functions and were converted into fences. As the slopes of the Lavra ravine and adjoining territories were actively built-up, and the religious buildings were restored and reconstructed, in the last century, the retaining stone walls were erected for the re- inforcement of slopes and the formation of horizontal platforms (terraces) for the construction of buildings.

Within the Upper Lavra, the retaining wall with a site, structure No. 30a (Fig. 2, 4), ensures the operation of buildings Nos. 29, 30, and 86 . It was erected in the $18^{\text {th }}$ century. in order to create a horizontal platform at the level of the Assumption Cathedral, the Belfry, and the Metropolitan's House. The formed terrace was used as an observation deck where, in 1883, an icon-painting school and workshop (building No. 30) were built. The maximum height of its separate sections is $13 \mathrm{~m}$. Today, the wall is in unsatisfactory condition (there are many places with dense crack patterns) and needs to be repaired (reinforcement and restoration of the lining).

On the left side of the Lavra ravine, at the entrance to the Near Caves, the wall of Daniel de Boskette, structure No. 77 (Fig. 2, 6), forms a space for the engineering structures - buildings Nos. 36, 41, and 48. The wall is up to $150 \mathrm{~m}$ long and up to $20 \mathrm{~m}$ high, has a good architectural design with a rotunda; the width of the wall is about $6.0 \mathrm{~m}$, at the top, and about $8 \mathrm{~m}$, at the bottom. It was designed by military engineer Daniel de Boskette, in 1744-1748, to stabilize the EGPs on the hills, which got intensified as a result of interference in the natural environment: the devastation of forests and the failure of surface and underground drains. Probably, the wall was built not only for retaining the slope, but also for forming a terrace for the placement of religious buildings, in particular, the Church of the Exaltation of the Holy Cross (1700) and the entrance to the Near Caves (building No. 41, 1751). In 2012, the de Bosquet wall had numerous surface damages of the lining (about 40\%) and vertical cracks.

The de Bosquet Wall is an architectural monument of Ukraine (No.893/71-Kв). Today, as compared with 2012, the external wall lining has been restored, the wall is equipped with a system of advanced geodetic control sensors; the Reserve employees have been regularly monitoring its condition. 


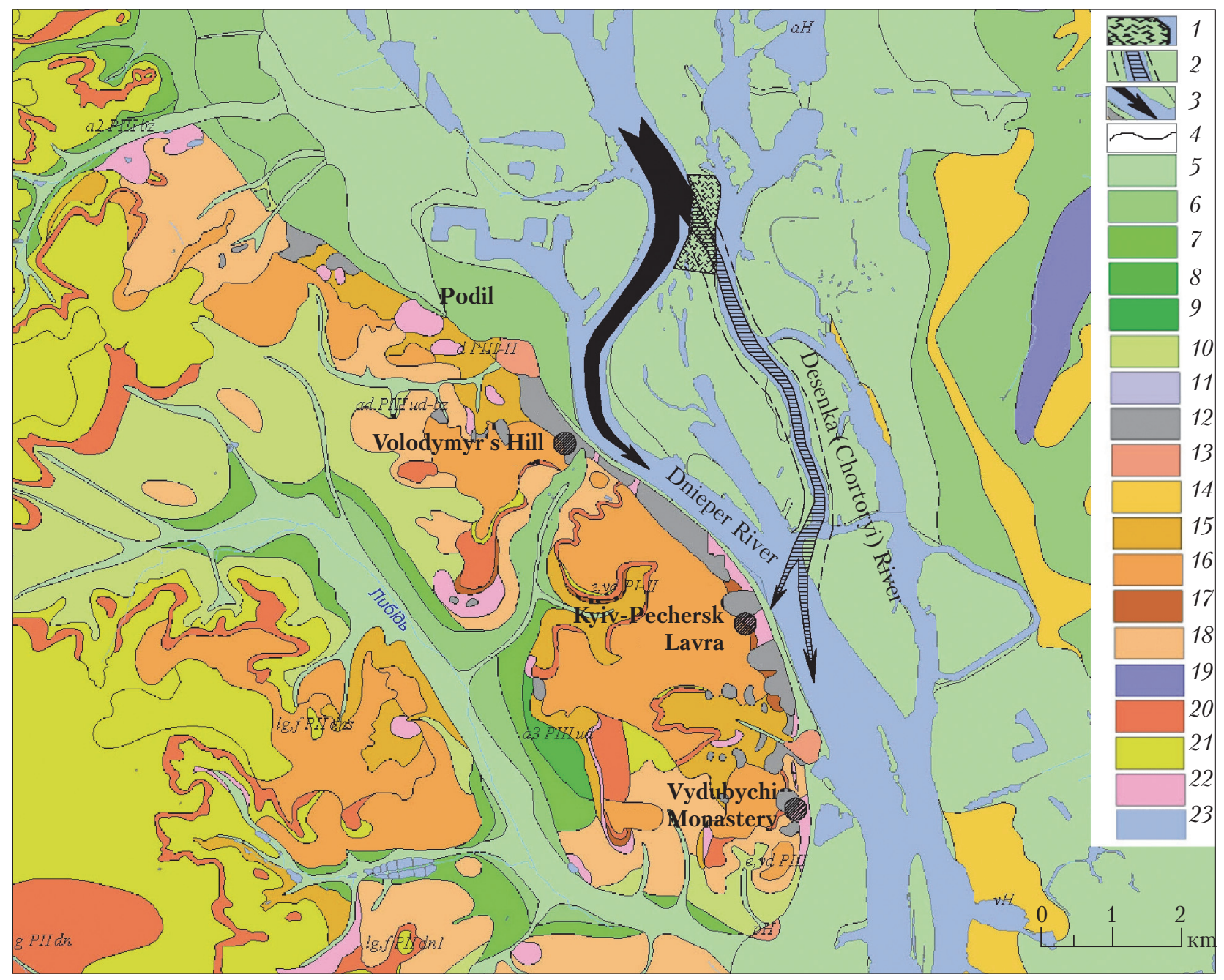

Fig. 1. Scheme of the Dnieper River mainstreams within the boundaries of Kyiv before and after damming of the Desenka (Chortoryi) River, in the mid-19 ${ }^{\text {th }}$ century: 1 - the section of the Chortoryi dam; 2 - reconstruction of the Dnieper River mainstream before damming; 3 - direction of the stream; 4 - boundaries of lithologic and genetic complexes; 5 - alluvial formations of the mainstreams and ravines. Sands, sandy clays, clay loams, aH; 6 - alluvial formations of the $1^{\text {st }}$ floodplain terraces of high and low levels of the Dnieper and the Desna Rivers. Sands, sandy clays a ${ }^{1} \mathrm{P}_{\mathrm{UI}} \mathrm{pc} ; 7-$ the Bug horizon. Alluvial formations of the $2^{\text {nd }}$ floodplain terraces of the Dnieper, Desna, Lybid, and Nyvky Rivers. Sands, sandy clays, $\mathrm{a}^{2} \mathrm{P}_{\text {III }}$ bz; 8 - the Udai horizon. Alluvial formations of the $3^{\text {rd }}$ floodplain terraces of the Dnieper and Desna Rivers. Sands, sandy clays, $\mathrm{a}^{3} \mathrm{P}_{\text {III }}$ ud; 9 - alluvial deposits of the $4^{\text {th }}$ floodplain terraces of the Dnieper and Desna Rivers. Sands, sandy clays, $\mathrm{a}^{4} \mathrm{P}_{\text {II }}$; 10 - alluvial deluvial formations of the ravine bottoms. Sandy clays, loams, sands, ad $\mathrm{P}_{\mathrm{III}}-\mathrm{H}$; 11 - boggy deposits of the mainstreams of rivers and ravines, low floodplain terraces. Peat, gyttija peat, sandy clays, bH; 12 - gravity deposits. Shear rocks of different lithological composition, gr H; 13 - proluvial deposits. Sands, sandy clays, loams, pH; 14 - Eolian formations. Sands, sandy clays, v $\mathrm{P}_{\mathrm{III}}-\mathrm{H}$; 15 - deluvial deposits. Sandy clays, loams, sands, d $\mathrm{P}_{\mathrm{III}}-\mathrm{H}$; $16-$ eluvial, Eolian and deluvial formations. Loess, loess-like loam, sandy loam, and fossil soils, e, vd $\mathrm{P}_{\text {III }}$;7 - the lower and middle levels are not separated. Eluvial Eolian and deluvial deposits. Sands, sandy clays, loams (including loess), fossil soils, e, vd $\mathrm{P}_{\mathrm{I}-\mathrm{II}} ; 18$ - eluvial and deluvial deposits. Loess-like loams, sandy loams, fossil soils, loess, ed $\mathrm{P}_{\mathrm{III}} ; 19$ - lacustrine and boggy deposits. Peat, mud, loam, sandy clays, lb $\mathrm{P}_{\mathrm{III}}-\mathrm{H} ; 20$ - glacial deposits (moraines). Boulder loam and sandy loam, g $\mathrm{P}_{\mathrm{II}}$ dn; 21 - glaciolacustrine and fluvio-glacial deposits. Loams, sandy loams, sands, (lg, f $\mathrm{P}_{\mathrm{II}} \mathrm{dn}$ ); 22 - quaternary formations, P-N; 23 - water area 


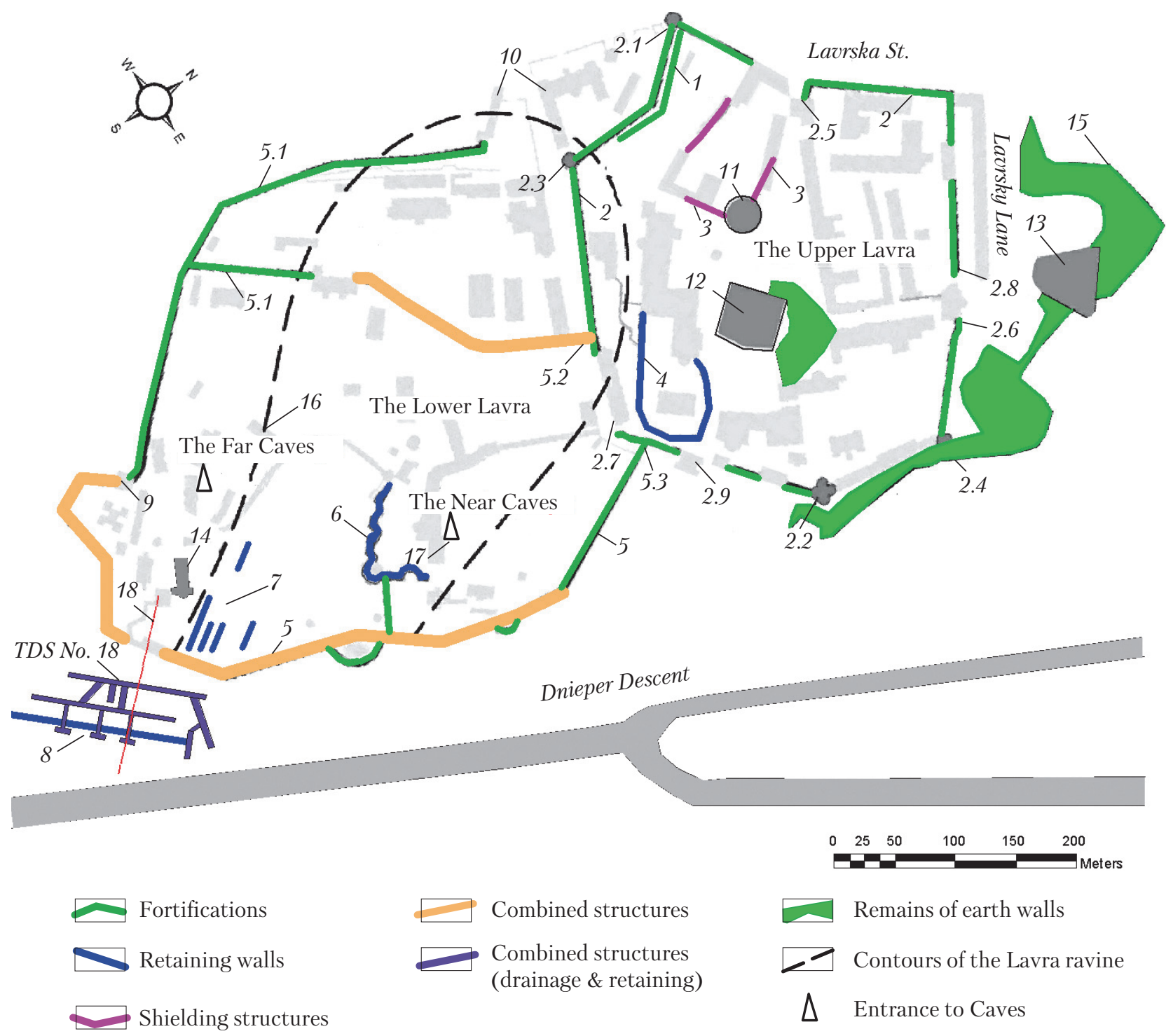

Fig. 2. Protective and defensive structures of the Upper and the Lower Lavra: 1 - remnants of defensive fortifications; 2 defensive fortifications of the Upper Lavra; 2.1 - the John Calabytes Tower; 2.2 - the Onufri Tower; 2.3 - the Southern (Clock) Tower; 2.4 - the Northern (Painting) Tower; 2.5 - the Economic Gate with the Church of All Saints; 2.6 - the Western Holy Gate with the Holy Trinity Church; 2.7 - the Southern (Lower) Gate; 2.8 - the Northern Gate; 2.9 - the Eastern Gate; 3 - wall with the gate near the Great Lavra bell tower; 4 - retaining wall of the terrace with observation deck; 5 - defensive walls of the Near and the Far Caves; 5.1 - retaining wall of the $3^{\text {rd }}$ line; 5.2 - the Entrance Gate; 5.3 - the Lower Gate at the entrance to the Near and the Far Caves; 6 - D. de Bosquet retaining wall; 7 - cascade of retaining walls on the right side of the Lavra ravine; 8 - integrated building designed by Peter Suchtelen; 9 - the bell tower in the Far Caves; 10 - the Western Gate with a guard house; 11 - the Lavra bell tower; 12 - the Assumption Cathedral; 13 - the Church of the Savior on Berestove; 14 - the Church of the Conception of St. Anna at the Far Caves; 15 - remnants of the earth walls; 16 - contours of the Lavra ravine; 17 - the entrance to the cave; 18 - cross section line (see Fig. 4) 


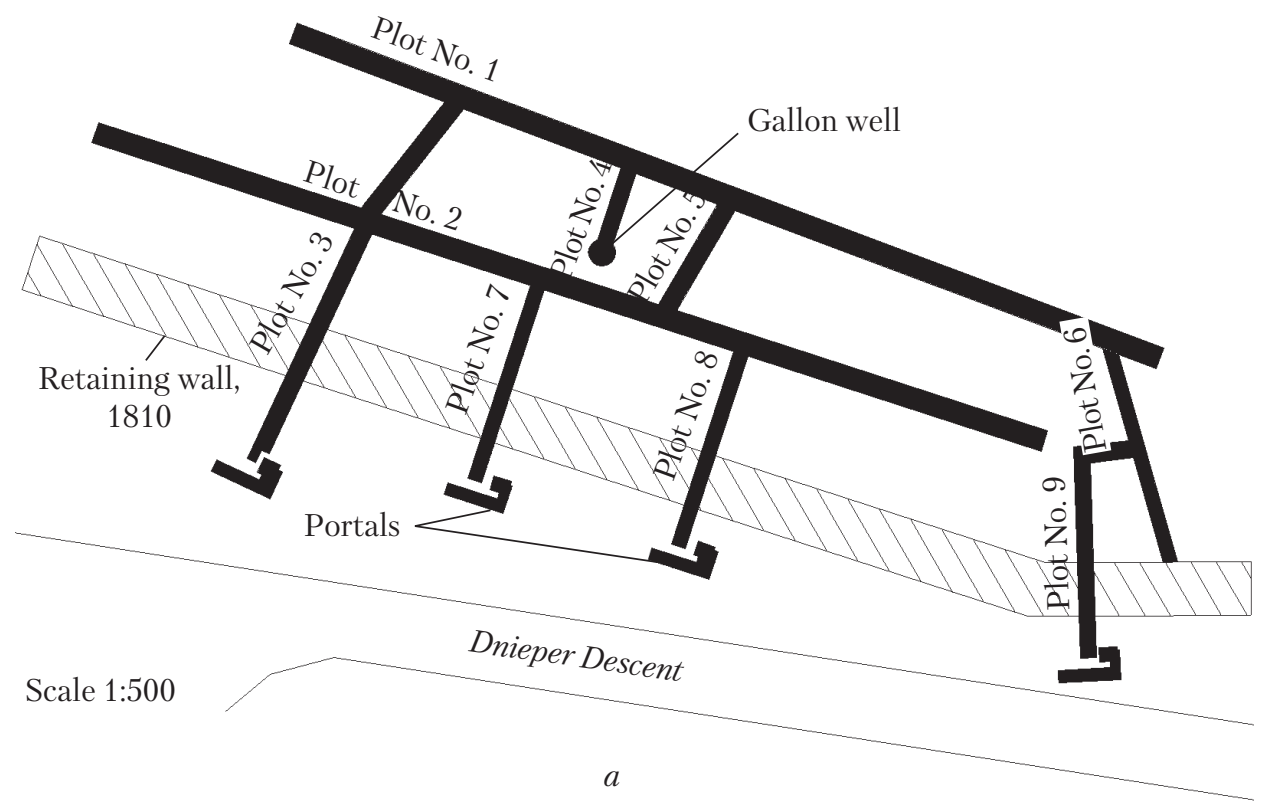

Fig. 3. Scheme of the position of the integrated building designed by Peter Suchtelen (TTD-18 and retaining wall) (a) and drainage tunnels $(b)$

The reinforcement of the right side of the Lavra ravine, near the Far Caves, where the influence of external factors has been evident (caving by the Dnieper River, disturbances of the geological environment caused by the construction of the Rozhdestvensky and the Spassky bastions, in particular, changes of the underground water conditions) required special measures to control the EGP and to retain the slopes. According to literary sources, even Czars (in particular, Alexander I) were engaged in solving the problems of soil stabilization there. To this end, various reinforcement measures were elaborated, among which, the Suchtelen project - the construction (1810) of a three-tier system: a retaining wall having a width of almost $8 \mathrm{~m}$ and two-tier drainages located at different levels (arched structures with an underdrainage for interception of ground waters (Fig. 3) was approved in 1806. These measures are considered the creation of an integrated retaining and drainage structure (Fig. 2, 8).

Despite the fact that the engineering structures were properly configured, their effective-

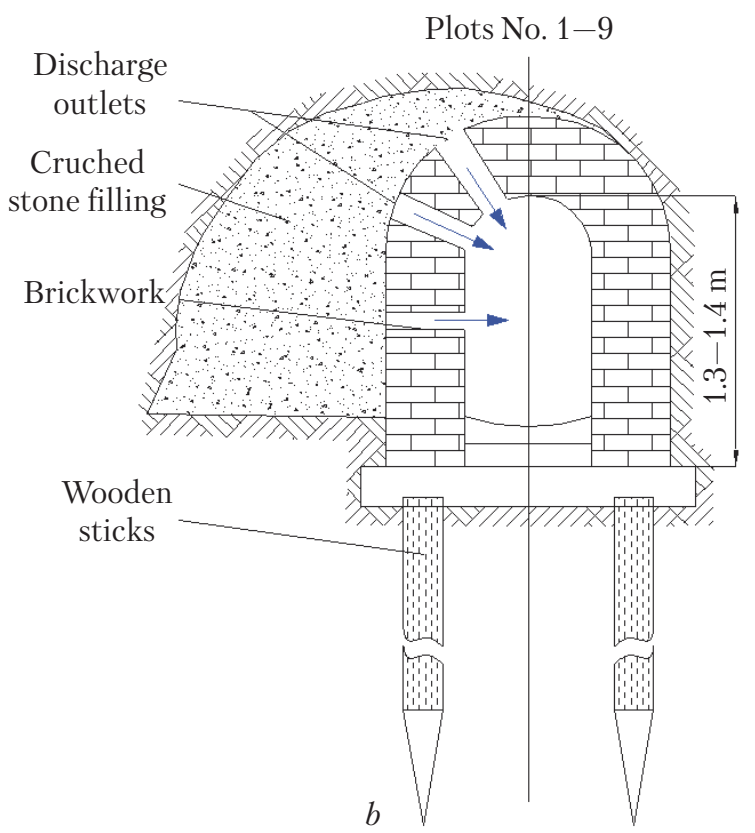

ness was not as high as expected. The landslides on this slope continued 200 years after the completion of construction works. This is assumed to be caused by improperly arranged surface drainage. Fig. 4 shows a model of the hill with the mentioned engineering structures; their ineffectiveness is explained by unsuitability of the complex for retaining a slope with developing plastic 
deformations and displacements. In this area, the sediments subject to displacement consist mainly of a fraction of clay rocks, since in the upper part of the slope, there are color and brown clays that are sensitive to meteorological conditions. Therefore, in this case, it is expedient to construct additional surface drainage systems and to properly maintain them.

On the right side of the Lavra ravine, in addition to the defensive wall constructed after a big landslide in 1971, which destroyed an almost $100 \mathrm{~m}$ long fence at the bottom of the ravine, a cascade of retaining walls (see Figs 2, 7) having a length from 10 to $40 \mathrm{~m}$ was built. In 2009-2010, signs of landslide processes were detected [11]: the expansion of cracks in the footpaths along the slopes; the formation of a vertical crack with an opening upward of $6-8 \mathrm{~mm}$ in the brickwork (pillar) and cracks of separation from the support of wooden structure in the gallery to the Far Caves; further expansion of bond-failure crack between the curb and the pavement and inclined lantern poles on the edge of the Lavra ravine slope, on the northern side of the building No. 67, etc. The analysis of materials of previous studies has indicated that the localization of these cracks is associated with the landslide of 1971. The nature of slides indicates a long process of soil mass deformation as a result of constant waterlogging and activation of landslides. Deformations and damages of the caves (cracks in the walls, sinks, and overbreaks), in particular, in the Church of the Nativity of Christ, are also likely to be caused by changes in the stability of the soil massif, and, possibly, by the development of deep landslide.

The retaining wall ( built in the second half of the $19^{\text {th }}$ century, which is a national monument "Defensive Wall around the Near and the Far Caves", extends from the building No. 71 to the building No. 65 (see Figs. $2,5.1)$. It was constructed on the plateau edge and protected the territory of the Hospitable Court located within the limits of the $32^{\text {nd }}$ slide circle on the western side, which predetermined the development of erosion and landslide processes and forced the monastery administration to build fortifications of various kinds. The wall was not suitable for defensive function as it had no loopholes, its strength and height were insufficient. Field inspections of the retaining wall on the site No. 3 have shown that it has numerous damages in the form of horizontal and vertical cracks, falling away of bricks and mortar, protrusions and inclinations in the area against the building No. 65, masonry deformation and destruction of the upper masonry layer. The main factors of deformation processes were waterlogging of the soil mass as a result of snow melting in 2013 [12] and failure of drainage systems.

The construction of the Dnieper (Nicolas') Descent (1852-1860) linking the upper part of the loess plateau and the approach to Naberezhne Highway and to the Chain Bridge (designed by architect Kiberza) significantly affected the soil massif condition. In parallel with the construction of the descent, there was built a trenchtype drainage (TTD-17) that today ensures the stability of the descent embankment. In the same period, the TTD-23, TTD-17-bis, and the "drainage gallery of the Lavra ravine" were installed; these structures are operating more or less effectively as they are dewatering the soil in the approaches to the Spassky ravine descent. The drainage facilities of this type have also been constructed in the Lavra ravine and, as of today, have proved themselves to be quite effective.

The artificial drainage for the second aquifer groundwater was firstly used in 1798-1810 by engineer Peter Suchtelen, when an integrated drainage structure was built. It has been preserved to date (partially, as part of the system No. 18, see Figs. 2 and 3). As of today, several tens kilometers of such drainages have been constructed. They were laid in the slope massifs, in some places, in two or even three levels for interception of the Quaternary groundwater aquifers in the Kharkiv formation sands. The drainage is made in the form of trench with a brick collector arranged on piles in such a way as it acts as re- 


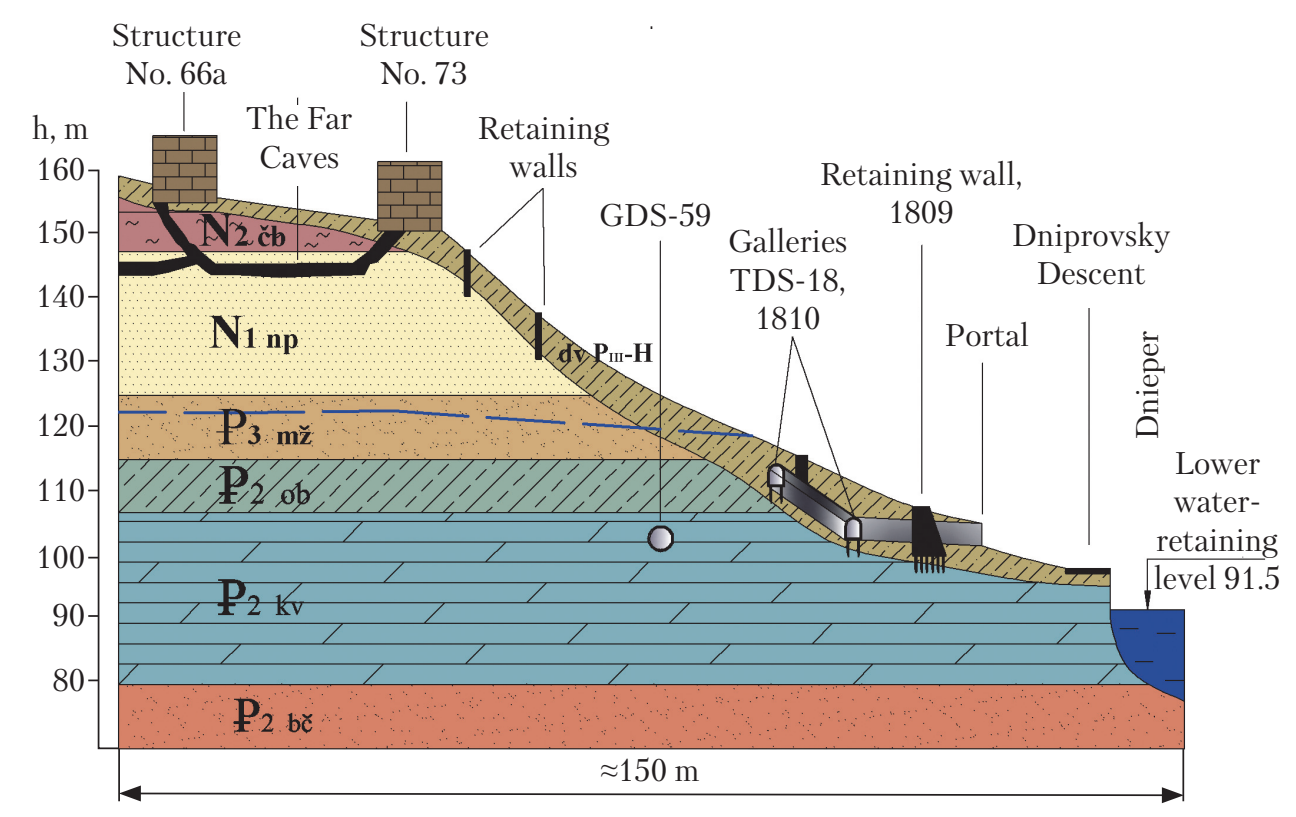

Fig. 4. Scheme of reinforcement of the slope near the Lavra ravine

(the position of the line of the line in terms of the look fig. 2, p. 18)

taining wall (see Fig. 3, construction) or has a trapezoidal cross section. The underground water is drained out by gravel filling.

In terms of configurations, the TTDs on the Lavra territory are divided into several types:

1. The deep drainage trenches with brick water-collecting galleries, with vents for receiving water. The ground waters are drained through drainage filling. These are the first TTDs (TTD-18 (1798-1810) and TTD-17 (1850-1860)) constructed in order to prevent landslides in the territory of the Kyiv-Pechersk Lavra and the Pankratovy ravine. Without any reconstruction, they have been successfully operating till nowadays.

2. The culvert-type drainage systems with a cross section in the form of a trapezoid having a size of $0.9 \times 1.1 \times 1.8 \mathrm{~m}$, the drainage galleries of which were fixed with oak square sets. They started to be built from the beginning of the $20^{\text {th }}$ century. Their $1.6 \times 1.6 \mathrm{~m}$ and $1.7 \times 1.7 \mathrm{~m}$ drainage wells were fixed with pine timberworks that collapsed in 4-10 years, depending on the conditions and the quality of wood. Only after 1960s, these culvert systems began to be fixed with reinforced concrete beams.
3. The gallery-type drainage systems (GDS) made using the panel method started to be used since 1972, with galleries fixed with round reinforced concrete tubes having $1 \mathrm{~m}$ in length and 1.8-2.2 $\mathrm{m}$ in diameter. On the Reserve's territory, GDS 59 are installed.

The complex surveys of TTD No.16, TTD No. 27-bis, TTD No. 27 and leakages from these systems have been carried out by the Institute of Geological Sciences of the NAS of Ukraine in order to estimate the soil permeability around the drainage tunnel systems and to study its impact on the hydrogeological conditions and the stability of slopes.

Many-years observations have shown that the effectiveness of draining by the "body" of the tunnel decreases as new formations (outgrowths and stalactites) arise and complicate the flow of groundwater. At the same time, the debit of "body" drainage increases significantly after cleaning the outgrowths mudding the holes between the beams.

The drainage systems laid in the lower part of the slope to discharge groundwaters of the Kharkiv aquifer are characterized by relative sta- 

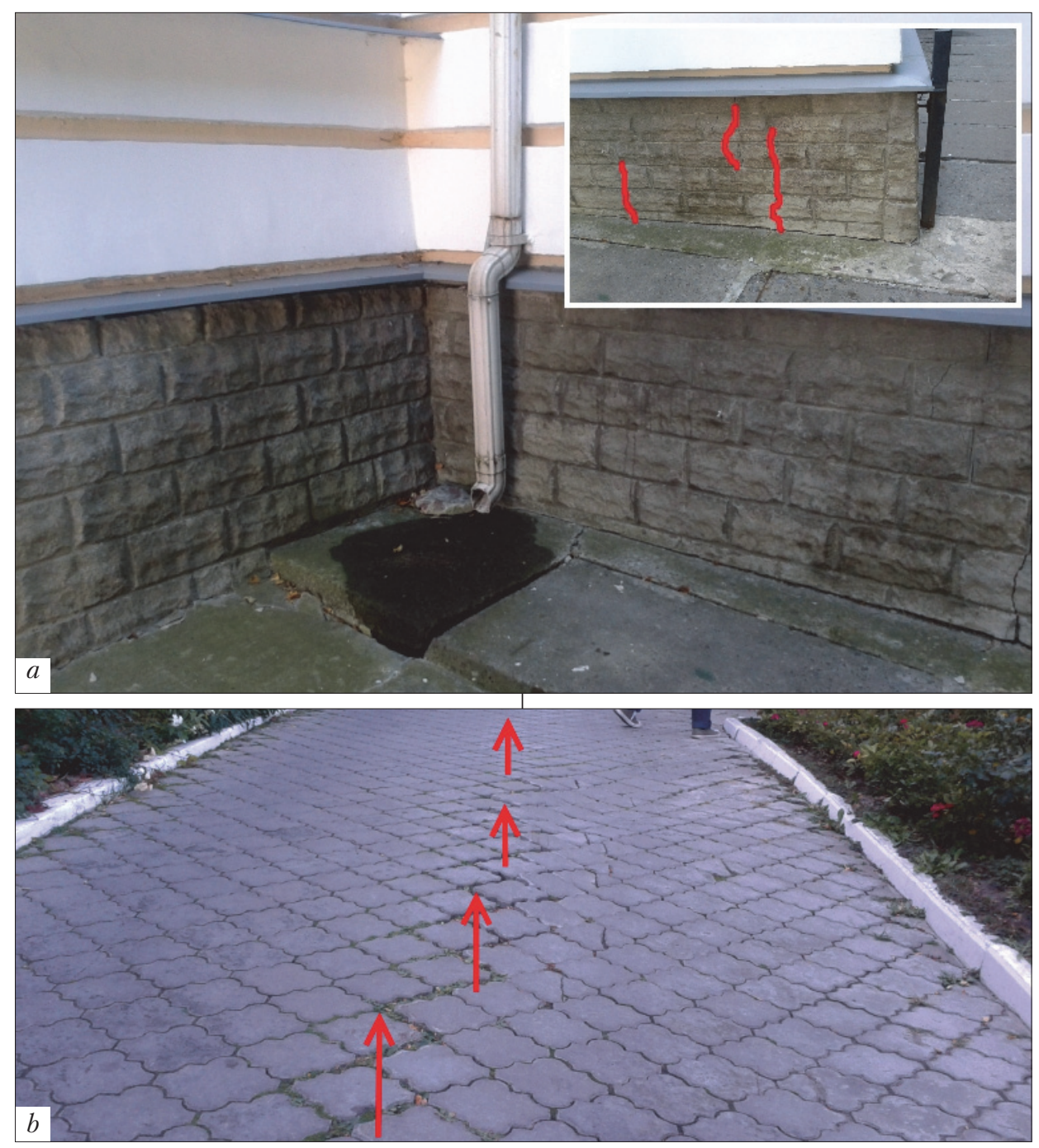

Fig. 5. Deformations of the facing and waterlogging of the foundations of buildings No. 51$52(a)$ and swelling of the pavement near them $(b)$. The arrows show the greatest deformation

bility of the flow rate during the whole time of their operation. The "body" is usually laid in marl clay or in thin black soil layer above the clay of the Kyiv formations, with 6-8 m long filters led into the thin black soil layer or into the sands of the Kharkiv formations. Moreover, when the debit of some filters decreases, as a rule, that of the neighboring ones increases, so that the total water inflow remains relatively constant.

The coefficients of drainage effectiveness have been estimated for the Lavra TTD. As a result, TTD-17, TTD-17-bis are considered effective,
TTD-27, TTD-27-bis, TTD-28 (in the area between wells 6-13) are partially effective, and TTD-28-bis, TTD-18, TTD-55 are ineffective. Moreover, TTD-55 in the place of connection with TTD-28, TTD-52, and TTD-23-24 cannot be considered as actually they do not drain, but evacuate water (TTD-28), or act as louver above the caves (TTD-52). TTD-59, although partially performs drainage functions, does not contribute to the stability of the slope [2]. Also, it is necessary to consider feasibility of operation of drainage galleries in the buffer zone of the Reserve 
(GDS Dnipro), which, since their construction (1972), neither have been draining the second aquifer waters, nor preventing landslides.

On the Reserve's territory, there is a developed network of shallow tubular rainwater drainages. The densest grid of surface water drainage there is at the Lower Lavra. The intercepted surface waters from there come to shallow brick galleries (No. 1-4) and are discharged to the Dnieper River. Improper maintenance of drain pipes leads to the slaking of foundations of historic buildings and deformations of pedestal faceworks, as shown in Fig. 5

In the areas where the landslides occurred, in addition to the construction of drainage systems, other works (land planning, groundwater evacuation, etc.) have been performed. Therefore, it is impossible to estimate the effect of preventing landslides and the feasibility of constructing each individual system.

\section{CONCLUSIONS}

The engineering and economic development of the hill and effectiveness of the engineering protection of the Reserve territory have been analyzed at different times, for various purposes, while implementing the project "Improvement of the Engineering Protection Systems of the Territory of the Kyiv-Pechersk Lavra National Historical and Cultural Reserve". The construction of religious buildings and monastery household premises took place at the same time with the organization of the relief around the Lavra ravine with the use of masonry walls for retaining the slopes and the creation of horizontal platforms (terraces) for the location of buildings.

The state and the nature of the development of processes on the Reserve territory are determined by the engineering and geological conditions. The stability of the slope and structures on it depends on the strength properties of mottled and brown clay. In the natural state, the loess soils have a rather high strength, however, under additional load or if they are waterlogged as a result of leakage and failure of drainage systems, the loess soils can sink (I type of soil conditions), which leads to deformation of the surface and structures. Structural deformations are accompanied by an inclination, a curvature of the bearing structures, swelling and cracking of the walls with openings of $10-12 \mathrm{~cm}$. In the case of uneven subsidence of the loess soils, in the strip footing under the walls of the monuments, often there occur cracks in the zones of maximum deflection. Loess soils subside quickly. The sharp violation of the natural conditions of loess soils during construction leads to uneven subsidence of structures as a result of soil subsidence, mechanical and chemical suffusion.

Significant changes in the stress-strain state of the soil mass, hydrogeological conditions and surface discharge are dated the late $17^{\text {th }}$-early $18^{\text {th }}$ centuries when during the construction of bastion-type fortress, the earthworks of about $500000 \mathrm{~m}^{3}$ were done and the forest cover was destroyed.

During the inspection of the territory, there have been found deformations and cracks in the structures, deformations of the road pavement, wet corners of the foundations and pedestals of buildings.

Therefore, the main recommendations for improving the engineering protection systems on the Reserve's territory are as follows:

1. To ensure proper maintenance of surface water discharge (the timely repair of chutes, wells, and collectors. Particular attention is needed to the water-supply, sewage, and heating systems, drainpipes and stormwater intakes, which must be cleaned and repaired in a timely manner.

2. To repair or to reinforce all support structures, to clean the drainage facilities, to separate the surface water discharge from the drainage system (to prevent mud accumulation).

3. To establish a moratorium on the further development of underground space at the level of waterproof layers in red-brown clay and marl clay of the Kyiv formations.

4. To supervise over the development of deformations of deep galleries (TTD-28, TTD-52, and 
TTD-55), to detect emergency areas of these systems, and to develop remedial measures. On the basis of the research results, it is expedient to develop a system for removing the emergency areas out of service by the backfilling method.

5. An alternative to deep drainage facilities is the arrangement of new structures of surface drainage (shallow radial drainage).

6. Planting trees and landscaping of the territory is one of the important measures to ensure the stability of the geological environment and historical and cultural objects. The maximum attention should be paid to the condition of vegetation, gardens and mini-parks of the Reserve. Particular attention should be paid to the gardens above the Near Caves, because the caves wreckages were caused by a significant uncontrolled watering of fruit trees. It is also worthwhile to monitor the tree vegetation. On the slopes, in the places of discharge of aquifers, it is necessary to plant trees with a high transpiration capacity and to regularly, in a timely manner, remove dead wood.

The system of engineering protection on the Lavra territory shall be considered in the context of the entire territory of the right bank of the Dnieper River and Kyiv as a whole. To do this, it is necessary to organize a body that would monitor the development of negative processes in the city and to provide recommendations for their prevention and elimination. The existing monitoring department of the Reserve real estate objects should be considered a subdivision of this body. The condition of the caves, as well as control of its condition and ensuring of stability against landslides shall be included in the program for the development of engineering protection of this territory.

\section{REFERENCES}

1. Kyrychko, I. M. (1957). Construction of shallow drains in landslide areas (Generalization and analysis of the experience of the construction of drainage on examples of Kiev landslides). $\mathrm{PhD}$ (Techn.) [in Russian].

2. Demchyshyn, M. G., Kril, T. V., Cherevko, I. A. (2017). Improvement of the engineering protection systems of the territory of National historical and cultural reserve "Kiev-Pechersk Lavra". Report on research work. Institute of Geological Sciences of the National Academy of Sciences of Ukraine. Kyiv [in Ukrainian].

3. Demchyshyn, M. G., Kril, T. V., Anatsky, O. M. (2014). State of draft systems of a right-bank slope of Dnepr at the territory of a historical and cultural heritage in Kyiv. Geologichnyy zhurnal, 2, 85-94 [in Ukrainian].

4. Kril, T. (2017, June). Causes of some hazardous engineering geological processes on urban territories. $3^{\text {rd }}$ International Conference on Applied Geophysics E3S Web of Conferences. V. 24. doi:10.1051/e3sconf/20172401009.

5. Oppokov, Ye. (1921). Kyiv coastal drafts and struggle with them. Geologichnyy zhurnal, I (1), 40-60 [in Ukrainian].

6. Lichkov, L. S. (1938). On the question of the regime of landslides in the vicinity of the city of Kiev and its environs. Geologichnyy zhurnal, 4, 145-194 [in Russian].

7. Lohvin, N. (1998, 26 March). How does the Kiev-Pechersk Lavra die. Kyevskye vedomosty, 12-13 [in Russian].

8. Demchyshyn, M. G. (2005). Strengthening the slope above the Park Road on the site from Parkova Road to Musical stage. Report on research work. Institute of Geological Sciences of the National Academy of Sciences of Ukraine. Kyiv [in Ukrainian].

9. Kril, T. V. (2015). Technogenic dynamic influences on the geological environment of city (on an example of Kyiv). Kyiv: Naukova dumka [in Ukrainian].

10. Tale of Bygone Years: chronicle (for Ipatskiy list). (1990). Translated from the Old Rus., Afterword, comments V.V. Yaremenko. Kyiv: Radianskyi Pysmennyk, 558 p. [in Ukrainian].

11. Cherevko, I. A. (2016). Engineering-geological conditions of the Dalhepecherny hill in the context of preservation of cultural heritage objects. Collection of scientific works «Mohylianski chytannia - 2015». Natsionalnyi Kyievo-Pecherskyi istoryko-kulturnyi zapovidnyk. 306-313 [in Ukrainian].

12. Cherevko, I. A. (2014, May). Region \# 3 of the Defensive Wall around the Near and Far Caves: the issue of attribution, technical condition, factors of destruction and means of prevention. Materials of conference "Church - Science - Society: Interaction Issues", 59-64 [in Ukrainian].

Received 23.07.18 


\author{
Демчишин М.Г., Кріль Т.В. \\ Інститут геологічних наук НАН України, \\ вул. О. Гончара, 55 б, Київ, 01054, Україна, \\ +380 44486 3023, DemchyshynMG@nas.gov.ua \\ ВДОСКОНАЛЕННЯ ІНЖЕНЕРНОГО ЗАХИСТУ \\ ТЕРИТОРІЇ ЗАПОВІДНИКА «КИЄВО-ПЕЧЕРСЬКА ЛАВРА»
}

Вступ. Територія заповідника «Києво-Печерська Лавра» розташована у складних інженерно-геологічних умовах на правобережних схилах долини Дніпра й прилеглих до неї ділянок лесового плато. Стабільність та збереження об'єктів Лаври забезпечується системою спеціальних утримуючих та водорегулюючих споруд інженерного захисту.

Проблематика. Більшість зазначених споруд було закладено в різні періоди і не завжди мало належне обгрунтування та виконання. Із розбудовою Заповідника змінювались умови їх експлуатації, тому виникає необхідність перегляду ефективності їх роботи як захисних споруд та подальше удосконалення.

Мета. Визначення обгрунтованості, адекватності, ефективності та стану систем інженерного захисту території Заповідника для їх вдосконалення та запобігання надзвичайним ситуаціям.

Матеріали й методи. Використано схему інженерного захисту території (М 1:1000); план наявного стану території Заповідника (М 1:1000); дані інженерно-геологічних розвідувань різних часів, історичні та археологічні матеріали. Для визначення стану об’єктів інженерного захисту здійснено натурні спостереження (встановлення марок, фотофіксація). При оцінці стійкості території Заповідника використано механіко-математичні основи інженерної геології в комплексі з підходами системного аналізу та теорії інженерно-геологічної подібності.

Результати. Встановлено, що схилові процеси на досліджуваній території обумовлені активним розмивом правого берега Дніпра на цій ділянці, значними обсягами земляних робіт при розбудові Печерської фортеці у XVIIXVIII ст., а також неадекватністю окремих інженерних споруд масштабам і характеру розвитку інженерно-геологічних процесів та їх низькою ефективністю.

Висновки. Вдосконалення систем інженерного захисту полягає у підвищенні рівня технічної експлуатації споруд, поєднанні іх роботи із заходами благоустрою й озеленення, налагодженні системи моніторингу, врахуванні сезонності та аномальності проявів гідрометеорологічних процесів. Впровадження отриманих науково-технічних результатів дозволить підвищити ефективність систем інженерного захисту для охорони й збереження об'єктів Заповідника.

Ключові слова: інженерно-геологічні умови, зсув, провали, суфозія, інженерний захист, укріплення схилів.

\author{
М.Г. Демчишин, Т.В. Криль \\ Институт геологических наук НАН Украины, \\ ул. О. Гончара, 55 б, Киев, 01054, Украина, \\ +380 44486 3023, DemchyshynMG@nas.gov.ua \\ УСОВЕРШЕНСТВОВАНИЕ ИНЖЕНЕРНОЙ ЗАЩИТЫ \\ ТЕРРИТОРИИ ЗАПОВЕДНИКА «КИЕВО-ПЕЧЕРСКАЯ ЛАВРА»
}

Введение. Территория заповедника «Киево-Печерская Лавра» расположена в сложных инженерно-геологических условиях на правобережных склонах долины Днепра и прилегающих к ней участков лессового плато. Стабильность и сохранение объектов Лавры обеспечивается системой специальных удерживающих и водорегулирующих сооружений инженерной защиты.

Проблематика. Большинство сооружений были заложены в разные периоды и не всегда имели надлежащее обоснование для строительства. С развитием Заповедника изменялись условия их эксплуатации, поэтому возникает необходимость пересмотра эффективности их работы в качестве защитных сооружений и последующее усовершенствование.

Цель. Определение обоснованности, адекватности, эффективности и состояния систем инженерной защиты территории Заповедника для их улучшения и предотвращения чрезвычайных ситуаций.

Материалы и методы. Использованы схема инженерной защиты территории (М 1:1000); план существующего состояния территории Заповедника (М 1:1000); данные инженерно-геологических изысканий, исторические и археологические материалы. Для определения состояния объектов инженерной защиты проводились натурные наблюдения. При оценке устойчивости территории Заповедника использованы механико-математические основы инженерной геологии в комплексе с подходами системного анализа и теории инженерно-геологического подобия. 
Результаты. Установлено, что склоновые процессы на этой территории были обусловлены активным размывом правого берега Днепра, значительными объемами земляных работ при возведении Печерской крепости в XVIIXVIII вв., а также неадекватностью отдельных инженерных сооружений масштабам и характеру развития инженерно-геологических процессов и низкой их эффективностью.

Выводы. Совершенствование систем инженерной защиты заключается в повышении уровня технической эксплуатации сооружений, сочетании их работы с мероприятиями по благоустройству и озеленению, налаживании системы мониторинга, учете сезонности и аномальности проявлений гидрометеорологических процессов. Внедрение полученных научно-технических результатов позволит повысить эффективность систем инженерной защиты для охраны и сохранения объектов Заповедника.

Ключевые слова: инженерно-геологические условия, оползень, провалы, суффозия, инженерная защита, укрепление склонов. 